https://helda.helsinki.fi

Methane Fluxes Into Atmosphere from Fennoskandian Lakes

Golubyatnikov, L. L.

2018-11

Golubyatnikov , L L \& Mammarella , I 2018 , ' Methane Fluxes Into Atmosphere from

Fennoskandian Lakes ' , Izvestiya. Atmospheric and oceanic physics, vol. 54 , no. 6 , pp.

570-580 . https://doi.org/10.1134/S0001433818060075

http://hdl.handle.net/10138/307108

https://doi.org/10.1134/S0001433818060075

cc_by

publishedVersion

Downloaded from Helda, University of Helsinki institutional repository.

This is an electronic reprint of the original article.

This reprint may differ from the original in pagination and typographic detail.

Please cite the original version. 


\title{
Methane Fluxes Into Atmosphere from Fennoskandian Lakes ${ }^{1}$
}

\author{
L. L. Golubyatnikov ${ }^{a, *}$ and I. Mammarella ${ }^{b, * *}$ \\ ${ }^{a}$ Obukhov Institute of Atmospheric Physics, Moscow, 119017 Russia \\ ${ }^{b}$ Institute for Atmospheric and Earth System Research, University of Helsinki, \\ Gustaf Hallstrominkatu 2, PO Box 64, Helsinki, FI-00014 Finland \\ *e-mail:golub@ifaran.ru \\ **e-mail:ivan.mammarella@helsinki.fi \\ Received November 28, 2017; in final form, March 20, 2018
}

\begin{abstract}
The experimental data on methane fluxes into the atmosphere from Fennoscandian lakes is analyzed. The contribution made by the lake network of this northern region to the atmospheric methane budget is estimated as $320 \pm 23 \mathrm{KtCH}_{4}$ per year. From 16 to $37 \%$ of the annual methane emission from Fennoscandian lakes is carried out by methane produced during the ice cover period. The methane fluxe rate from studied lakes is estimated as $2.6 \pm 0.2 \mathrm{gCH}_{4} \mathrm{~m}^{-2} \mathrm{yr}^{-1}$. Among lakes of the region, small lakes (area $<0.1 \mathrm{~km}^{2}$ ) are the most intensive sources of atmospheric methane per unit area.
\end{abstract}

Keywords: methane fluxes, lakes, natural zones, Fennoskandia

DOI: $10.1134 / \mathrm{S} 0001433818060075$

\section{INTRODUCTION}

Globally lakes cover $5.4 \times 10^{6} \mathrm{~km}^{2}$, which is about $3.7 \%$ of the surface area of the continents [1]. Despite the small surface area of the Earth occupied by lakes, these water bodies play an important role in the global and regional carbon cycles $[2,3]$. There is an accumulation of organic matter in the bottom sediments of lakes. As a result of this process, part of atmospheric carbon is removed from the global cycle. At the same time, lakes emit greenhouse gases into the atmosphere and, in particular, they represent one of the largest natural sources of atmospheric methane. The methane flux into the atmosphere from the world's lake network is estimated at 47-140 $\mathrm{MtCH}_{4}$ per year [4], which is $24-27 \%$ of the global methane emission from natural sources.

Methane in lakes is a result of organic matter decomposition of bottom sediments by microorganisms in the anoxic conditions. Methane formed in the bottom sediments is partially absorbed by a number of lake microorganisms in bottom sediments and on sediments surface [5]. Methane formed at the bottom of lakes can be emitted into the atmosphere through diffusion, ebullition (bubble flux from sediments) and vascular plants growing at shallow parts of lakes (plant-mediated flux) [6]. In case of a diffusion transport some methane is oxidized by methane-oxidizing bacteria in the lake water column, which leads methane emission to decrease. In case of ebullition the oxi-

\footnotetext{
${ }^{1}$ The article was translated by the authors.
}

dation of methane in the lake water column does not occur. The share of the methane bubble flux in its total emission from northern lakes over the warm season (ice-free period) can exceed $80 \%$ [3, 7, 8]. On some lakes there is no bubble emission of methane at all $[7,9]$. Vascular plants growing in the shallow-water part of lakes take methane formed in the bottom sediments by their roots and release it through their leaves into the atmosphere [6]. Methane emission from the shallow parts of some lakes by vascular plants can exceed $90 \%$ of the annual methane emission from lake shallow water $[10,11]$. The methane emission from lakes essentially depends on the amount of organic matter in the bottom sediments and on the physico-chemical properties of the lake water column [5]. Field studies have shown that the methane flux per unit area into the atmosphere from the deep-water part of the lakes is usually much less than the similar flux from the shallow-water part $[8,11,12]$.

The methane emission from lakes occurs continuously over the warm period. For many lakes in temperate latitudes with a distinct stratification of water column, a brief but intense efflux of methane into the atmosphere have been recorded during the autumn turnover of lake water $[6,13]$. Methane production in the northern lakes occurs also in the ice cover period before the freezing of the lake and its bottom sediments. Many tundra and boreal lakes remain unfrozen during the winter and methane production in these lakes occurs all year-round. The methane formed in the ice cover period accumulates in the lake water, partially freezes into ice and is intensively emitted into 
the atmosphere during a short period of ice thaw and spring lake mixing [14-17]. The spring methane flux into the atmosphere from particular lakes reaches $84 \%$ of the annual methane emission from them [15]. However, in some lakes there is no significant methane emission during ice thaw due to the activity of methaneoxidizing bacteria in the water column of these lakes over the winter and early spring periods [13].

Latitudes between $45^{\circ}$ and $75^{\circ} \mathrm{N}$ are characterized by the highest density of lakes [1]. In recent years, much attention has been paid to studies of the role of these lakes in carbon cycle at global and regional levels $[3,18-20]$. In this paper, we analyze the experimental data on methane emissions from Fennoscandian lakes and estimate the contribution of the lake network in this vast northern region to the atmospheric methane budget.

\section{MATERIALS AND METHODS}

Territory of Fennoscandia (Fig. 1) includes the Scandinavian and Kola peninsulas, territories of Finland and Karelia. In this study, Karelia is considered without the water areas of Onega and Ladoga lakes. There are tundra, forest-tundra and forest zones in the Fennoscandian territory [21]. Tundra zone is represented by landscapes of arctic and alpine (high-mountain) tundra, forest-tundra zone is represented by forest-tundra plant communities of the Kola and Scandinavian peninsulas. Forests of Fennoscandia are subdivided into zones of boreal forests (north-, middle- and south-taiga forests), mixed broadleavedconiferous forests and broadleaved forests.

The area of Fennoscandia is 1.5 million $\mathrm{km}^{2}$ and $9 \%$ of its territory is occupied by lakes [22, 23]. The largest areas of lake coverage for the territory of Fennoscandia are typical for Finland and Karelia-10 and $12 \%$ respectively $[23,24]$. In the region under consideration glacial and tectonic lakes predominate. Most of Fennoscandian lakes have a small area of water surface. For example, in Finland about 56 thousand lakes have a surface area over $0.01 \mathrm{~km}^{2}$, whereas there are more than 134 thousands lakes with an area less than $0.01 \mathrm{~km}^{2}$ [24], in Karelia only $2 \%$ of lakes have an area over $1.0 \mathrm{~km}^{2}$ [23].

A number of water bodies in the territory of Fennoscandia are reservoirs that are created on lakes and rivers. Due to the peculiarities of geological structure and relief of the region, when reservoirs were created additional flooded areas remained insignificant. Two large reservoirs in northern part of Finland Lokka $\left(\right.$ area $417 \mathrm{~km}^{2}$ ) and Porttipahta (area $214 \mathrm{~km}^{2}$ ) are an exception. When they were created, significant territories were flooded, more than 65 and $32 \%$ of which were occupied respectively by peat deposits and mineral soils [25]. The mineralization of organic matter found at the bottom of these reservoirs leads to more intensive methane emission from these reservoirs in comparison with natural lakes. Without loss of generality in this article reservoirs are included in the lake network of the region.

For this study, lake areas were obtained from water body database collected by the Finnish Environment Institute (http://www.syke.fi), Swedish Meteorological and Hydrological Institute (http://opendataview.smhi.se), Norwegian Water Information System (http://vann-nett.no). Lake networks for the Kola Peninsula and Karelia were analyzed on the basis of GIS technologies and satellite imagery MODIS available from the EarthExplorer portal of the US Geological Survey (https://earthexplorer.usgs.gov). According to the used databases, in the territories of Norway and Sweden lakes with a surface area from 0.01 and $0.001 \mathrm{~km}^{2}$ respectively were taken into account. Spatial resolution of satellite images MODIS allows to take into account water objects with an area from $0.06 \mathrm{~km}^{2}$. In the database of lakes in Finland, water bodies with a surface area of more than $1.0 \mathrm{~km}^{2}$ are mainly considered, and smaller lakes are partially taken into account. Areas of Finland lakes with a surfase area up to $1.0 \mathrm{~km}^{2}$ were refined according to data [24]. Information on the lake network and the geographical distribution of the natural zones (biomes) for Fennoscandia was processed using the ArcGIS software package.

In this study, the lakes are grouped into five size classes: small lakes have the surface areas less than $0.1 \mathrm{~km}^{2}$, middle lakes have the surface areas $0.1-1.0$ and $1.0-10 \mathrm{~km}^{2}$, large lakes have the surface areas $10-$ $100 \mathrm{~km}^{2}$ and more than $100 \mathrm{~km}^{2}$.

The contribution of the Fennoscandian lake network to the atmospheric methane budget was estimated on the basis of published data on methane fluxes into the atmosphere from the lakes in various regions of Finland and Sweden and of field research data obtained at the lakes of Paanajarvi National Park in Republic of Karelia. Calculations of the annual methane emission from lakes of Fennoscandian natural zones were carried out on the basis of the lake network areas and durations of the emission period in these zones. When calculating the annual methane emission from forest lakes of the region, the deepwater and shallow-water areas of lakes were taken into account. In this paper, as in [26], the methane emission period characteristic of the natural zone under consideration is the growing season of this zone, i.e. period with a daily mean near-surface air temperature no less than $5^{\circ} \mathrm{C}$.

\section{RESULTS AND DISCUSSION}

Natural zones of Fennoscandia, their climatic characteristics and lake covers. Analysis of cartographic information on European vegetation [21] showed that about $64 \%$ of the territory of Fennoscandia is occupied by boreal forests. Tundra and forest-tundra land- 




Fig. 1. Geographical distribution of natural zones in Fennoscandia: 1-Alpine tundra, 2-Arctic tundra, 3-Forest-tundra, Kola Peninsula, 4-Forest-tundra, Scandinavian Peninsula, 5-Northern boreal forest, 6-Middle boreal forest, 7-Southern boreal forest, 8-Mixed forest, 9-Broadleaved forest.

scapes cover more than $26 \%$ of the area under study. Zones of mixed and broadleaved forests represent about 10 and $1 \%$ of the Fennoscandian territory respectively.

The main climatic characteristics for natural zones of Fennoscandia were calculated from the data taken by 62 meteorological stations located in the different natural zones of the study territory for the period from 1994 to 2014 (Table 1). Mean annual near-surface temperature varies from -1.0 to $3.4^{\circ} \mathrm{C}$ in northern regions of Fennoscandia and from 6.5 to $8.2^{\circ} \mathrm{C}$ in southern regions. For the territory under study, the warmest and coldest months are July and February, respectively. The average annual total precipitation increases from $500 \mathrm{~mm}$ for tundra in the north-eastern part of the territory under study to $860 \mathrm{~mm}$ in broadleaved forests in the south-west of the region. The growing period lasts 100-130 days in tundra zone and increases to 210-250 days in zones of mixed and broadleaved forests for the territory.

Calculated surface areas for the lake size classes in Fennoscandian natural zones are given in Table 2. 
Table 1. Main climatic characteristics of natural zones in Fennoscandia

\begin{tabular}{|c|c|c|c|c|c|c|}
\hline \multirow{2}{*}{ Natural zones } & \multicolumn{3}{|c|}{$T,{ }^{\circ} \mathrm{C}$} & \multirow{2}{*}{$P, \mathrm{~mm} / \mathrm{yr}$} & \multirow{2}{*}{$T_{>0},{ }^{\circ} \mathrm{C}$} & \multirow{2}{*}{ Veg, days } \\
\hline & year & February & July & & & \\
\hline Arctic tundra (ArcT) & 1.8 & -6.6 & 10.8 & 507.9 & 1388.5 & 130.0 \\
\hline Alpine tundra (AlpT) & -1.0 & -8.8 & 8.7 & - & 905.2 & 99.0 \\
\hline Forest-tundra, Scandinavian Peninsula (FoT_Sk) & 3.4 & -5.8 & 14.3 & 951.5 & 2062.8 & 168.7 \\
\hline Forest-tundra, Kola Peninsula (FoT_Ko) & 0.0 & -12.3 & 13.1 & 497.3 & 1484.3 & 128.7 \\
\hline Northern boreal forest (NBF) & 1.5 & -11.0 & 15.3 & 493.9 & 1853.2 & 145.4 \\
\hline Middle boreal forest (MBF) & 3.0 & -8.7 & 16.2 & 620.9 & 2130.7 & 161.3 \\
\hline Southern boreal forest (SBF) & 5.2 & -5.4 & 17.1 & 669.5 & 2482.0 & 184.4 \\
\hline Mixed forest (MixF) & 6.5 & -3.1 & 17.4 & 734.5 & 2767.3 & 210.9 \\
\hline Broadleaved forest (BrLF) & 8.2 & 0.4 & 17.3 & 857.2 & 3134.5 & 251.6 \\
\hline
\end{tabular}

$T$ is near-surface air temperature, $P$ is annual precipitation, $T_{>0}$ is the sum of positive temperatures, Veg is the duration of growing season. Climatic characteristics were obtained from data collected by the The European Climate Assessment \& Dataset (http://www.ecad.eu/) and the All-Russian Research Institute of Hydrometeorological Information-World Data Center (http://meteo.ru/data/).

Table 2. Surface areas $\left(10^{3} \mathrm{~km}^{2}\right)$ for the lake size classes in natural zones of Fennoscandia

\begin{tabular}{|c|c|c|c|c|c|c|c|c|c|c|}
\hline \multirow{2}{*}{ Lake size class, $\mathrm{km}^{2}$} & \multicolumn{9}{|c|}{ Natural zones } & \multirow{2}{*}{ Total area } \\
\hline & ArcT & AlpT & FoT_Sk & FoT_Ko & NBF & $\mathrm{MBF}$ & SBF & MixF & BrLF & \\
\hline$<0.1$ & 0.1 & 0.4 & 1.7 & 0.1 & 1.4 & 1.2 & 0.9 & 0.2 & 0.04 & 6.0 \\
\hline $0.1-1$ & 0.4 & 0.8 & 3.2 & 0.3 & 4.0 & 3.5 & 2.8 & 1.5 & 0.1 & 16.6 \\
\hline $1-10$ & 0.4 & 0.5 & 3.6 & 0.4 & 6.5 & 6.1 & 4.6 & 2.5 & 0.2 & 24.8 \\
\hline $10-100$ & 0.3 & - & 4.2 & 0.3 & 7.6 & 5.4 & 5.1 & 2.5 & 0.1 & 25.5 \\
\hline$>100$ & - & - & 2.4 & 0.1 & 21.2 & 7.8 & 8.6 & 11.0 & - & 51.1 \\
\hline Total area & 1.2 & 1.7 & 15.1 & 1.2 & 40.7 & 24.0 & 22.0 & 17.7 & 0.4 & 124.0 \\
\hline
\end{tabular}

Names of natural zones are given in Table 1.

Territories of northern taiga, southern taiga and mixed forests of the region have the largest areas of the lake cover (11-13\%). Lakes cover 4,7 , and $8 \%$ of territories in the forest-tundra zone of Kola and Scandinavian peninsulas and in the middle taiga forests zone, respectively. The smallest areas of the lake cover $(2-3 \%)$ in the region are typical for tundra and broadleaved forests.

Methane fluxes into the atmosphere from subarctic lakes of Fennoscandia. Measurements of methane fluxes into the atmosphere from subarctic lakes of Fennoscandia were carried out near the Abisko Scientific Research Station $\left(68^{\circ} 21^{\prime} \mathrm{N}, 19^{\circ} 02^{\prime} \mathrm{E}\right.$; Sweden) $[15,27-31]$. Over the warm season diffusive methane fluxes from small lakes of the district into the atmosphere varies from 4.5 to $69.1 \mathrm{mgCH}_{4} \mathrm{~m}^{-2} \mathrm{~d}^{-1}[15,27]$ with average value $21.7 \mathrm{mgCH}_{4} \mathrm{~m}^{-2} \mathrm{~d}^{-1}$. According to data given in [15] the average daily diffusive methane flux from middle lakes is estimated at $5.4 \mathrm{mgCH}_{4} \mathrm{~m}^{-2}$ with variability from 3.2 to $8.0 \mathrm{mgCH}_{4} \mathrm{~m}^{-2} \mathrm{~d}^{-1}$. According to [28] the diffusive methane flux from the largest lake Tornetrask (area $345 \mathrm{~km}^{2}$ ) of the district is about $7 \%$ of the mean methane emission from small and middle lakes of the district which was estimated at $12 \pm 8 \mathrm{mgCH}_{4} \mathrm{~m}^{-2} \mathrm{~d}^{-1}$ [30]. Taking into account these data, we estimated the diffusive methane flux from large lakes in the northern part of Fennoscandia as $0.9 \mathrm{mgCH}_{4} \mathrm{~m}^{-2} \mathrm{~d}^{-1}$. According to [29] during the warm period the share of bubble emission in the methane flux into the atmosphere from subarctic lakes of Sweden varies from 46 to $81 \%$ and average value is $64 \%$. The short-term spring methane effluxes during the ice thaw into the atmosphere for lakes of this region are $3-84 \%[15,27,30,31]$ (average value is 37\%) of annual methane emissions from these lakes.

The obtained estimate for the diffusive methane flux from small lakes in the subarctic region of Fennoscandia is comparable to the average values of diffusive fluxes from small lakes in the north of Yakutia (22.6 $\pm 17.9 \mathrm{mgCH}_{4} \mathrm{~m}^{-2} \mathrm{~d}^{-1}$ according to [32]) and in tundra and forest-tundra of Alaska (21.2 \pm $11.6 \mathrm{mgCH}_{4} \mathrm{~m}^{-2} \mathrm{~d}^{-1}$ according to [20]). At the same time, the obtained estimate is significantly higher than the median values for diffusive methane fluxes from small lakes in forest-tundra of Western Siberia 


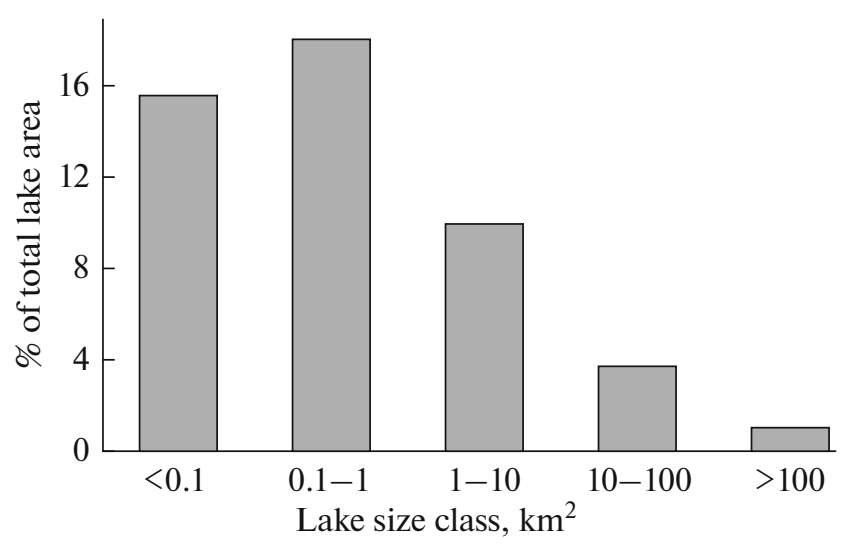

Fig. 2. Proportion of the total area of the lake size class occupied by shallow-water part of lakes for boreal zone in Fennoscandia $[10,12,23]$.

(5.3 $\left.\mathrm{mgCH}_{4} \mathrm{~m}^{-2} \mathrm{~d}^{-1}[33]\right)$, in tundra of Canada (12.8 $\mathrm{mgCH}_{4} \mathrm{~m}^{-2} \mathrm{~d}^{-1}$ [34]) and Western Siberia (2.7 $\mathrm{mgCH}_{4} \mathrm{~m}^{-2} \mathrm{~d}^{-1}$ [26]). The estimate for the diffusive methane flux from middle lakes in the subarctic region of Fennoscandia is less than the average value of similar fluxes from middle lakes in tundra and forest-tundra of Alaska $\left(12.1 \pm 5.4 \mathrm{mgCH}_{4} \mathrm{~m}^{-2} \mathrm{~d}^{-1}\right.$ according to [20]) and exceeds the median for methane fluxes from tundra lakes of Canada $\left(1.4 \mathrm{mgCH}_{4} \mathrm{~m}^{-2} \mathrm{~d}^{-1}\right.$ according to [34]). The obtained estimate of the average share of the bubble methane flux in the total methane emission over the warm season for lakes of the study region lies in the ranges of bubble methane emission reported for arctic lakes of Canada (20-65\% [34]) and for tundra and forest-tundra lakes of Alaska (9$90 \%$ [20]). Calculated average value of spring methane efflux into the atmosphere from subarctic lakes of Fennoscandia is close to the upper boundary of the range of methane emissions during the ice thaw from northern lakes of Alaska (4-26\% of annual methane emissions from lakes [20]).

Methane fluxes into the atmosphere from boreal lakes of Fennoscandia. Measurements of methane fluxes into the atmosphere from boreal lakes in Fennoscandia were carried out over deep-water parts and shallow-water areas with and without vegetation. According to $[10,12,23]$ middle lakes with a surface area of $0.1-1 \mathrm{~km}^{2}$ have the largest shallow-water parts among Fennoscandian boreal lakes (Fig. 2). According to [6, 7, 35-37] the highest diffusive methane emissions from the deep-water parts of the boreal lakes in the region are observed in small lakes (range is from 0.3 to $54.4 \mathrm{mgCH}_{4} \mathrm{~m}^{-2} \mathrm{~d}^{-1}$, average value is $\left.9.2 \mathrm{mgCH}_{4} \mathrm{~m}^{-2} \mathrm{~d}^{-1}\right)$. Based on $[6,7,35,36$, 38], diffusive methane fluxes into the atmosphere from the deep-water parts of middle lakes of the size classes of $0.1-1 \mathrm{~km}^{2}$ and $1-10 \mathrm{~km}^{2}$ are ranged between 0.6 and $4.7 \mathrm{mgCH}_{4} \mathrm{~m}^{-2} \mathrm{~d}^{-1}$ and between 1.7 and
$2.9 \mathrm{mgCH}_{4} \mathrm{~m}^{-2} \mathrm{~d}^{-1}$, respectively (average values for the fluxes are $2.3 \mathrm{mgCH}_{4} \mathrm{~m}^{-2} \mathrm{~d}^{-1}$ and $1.8 \mathrm{mgCH}_{4} \mathrm{~m}^{-2} \mathrm{~d}^{-1}$ ). According to [35, 37, 39] diffusive methane fluxes into the atmosphere from the deep-water parts of large lakes are ranged from 0.1 to $19.0 \mathrm{mgCH}_{4} \mathrm{~m}^{-2} \mathrm{~d}^{-1}$ with an average of $1.1 \mathrm{mgCH}_{4} \mathrm{~m}^{-2} \mathrm{~d}^{-1}$. It follows from [10, $11,40]$ that methane emission from shallow-water parts of boreal lakes in the region through vascular plants and diffusion varies from $75.2 \pm 13.1 \mathrm{mgCH}_{4} \mathrm{~m}^{-2} \mathrm{~d}^{-1}$ on small lakes to $212.3 \pm 20.7 \mathrm{mgCH}_{4} \mathrm{~m}^{-2} \mathrm{~d}^{-1}$ on large lakes. The diffusion methane flux in this emission can be $1-22 \%$ [41]. Several studies [7, 9, 11, 16] showed that the share of bubble methane flux to methane emission over the warm period from boreal lakes of the region can vary over a wide range $(0-86 \%)$ and their average values are 42 and $21 \%$ for the deep- and shallow-water parts of lakes respectively. According to [42] fraction of bubble methane flux in diffusion-bubble methane emission over the warm period from shallowwater parts of southern taiga lakes can be estimated at $56-79 \%$. It should be noted that data on the methane fluxes from lakes Lokka and Porttipahta are not taken into account in calculations of average values for the diffusive and bubble emissions of methane from boreal lakes. According to $[9,13,25,43,44]$ the short-term spring methane efflux during the ice thaw into the atmosphere from boreal lakes of the region vary from 0.01 to $3.5 \mathrm{gCH}_{4} \mathrm{~m}^{-2}$, which are $4.0-64.5 \%$ (average value $16.4 \%$ ) of the annual methane emission from these lakes. Studies [11, 44] showed that methane emission over the ice cover period from shallow-water parts of boreal lakes through vascular plants are 11$16 \%$ (average value $13 \%$ ) of the annual methane emission from these parts of lakes.

The obtained estimates for the diffusive methane flux from lakes in the boreal zone of Fennoscandia are close to the average values of diffusive methane fluxes from Canadian boreal lakes $\left(13.0 \pm 10.2 \mathrm{mgCH}_{4} \mathrm{~m}^{-2} \mathrm{~d}^{-1}\right.$ according to [45]), from small lakes of northern taiga and middle lakes of southern taiga in Alaska (18.7 \pm 0.5 and $17.1 \pm 1.3 \mathrm{mgCH}_{4} \mathrm{~m}^{-2} \mathrm{~d}^{-1}$ respectively, according to [20]). A wide range of changes for the share of the bubble methane emission in the total methane emission over the warm season for boreal lakes of the study region was also observed on boreal lakes of Alaska $(0-81 \%$ [20]) and Western Siberia (19-37\% [33]). The obtained value of the spring methane efflux into the atmosphere from boreal lakes of Fennoscandia is less than values of methane emissions during the ice thaw from boreal lakes of North America (40-44\% of annual methane emission from lakes $[14,46])$.

Methane fluxes into the atmosphere from mixed forests lakes of Fennoscandia. Measurements of methane fluxes into the atmosphere from lakes of the Fennoscandian mixed forests zone were carried out over the warm seasons in southern Sweden. Methane flux into the atmosphere by diffusion from the surface of small 


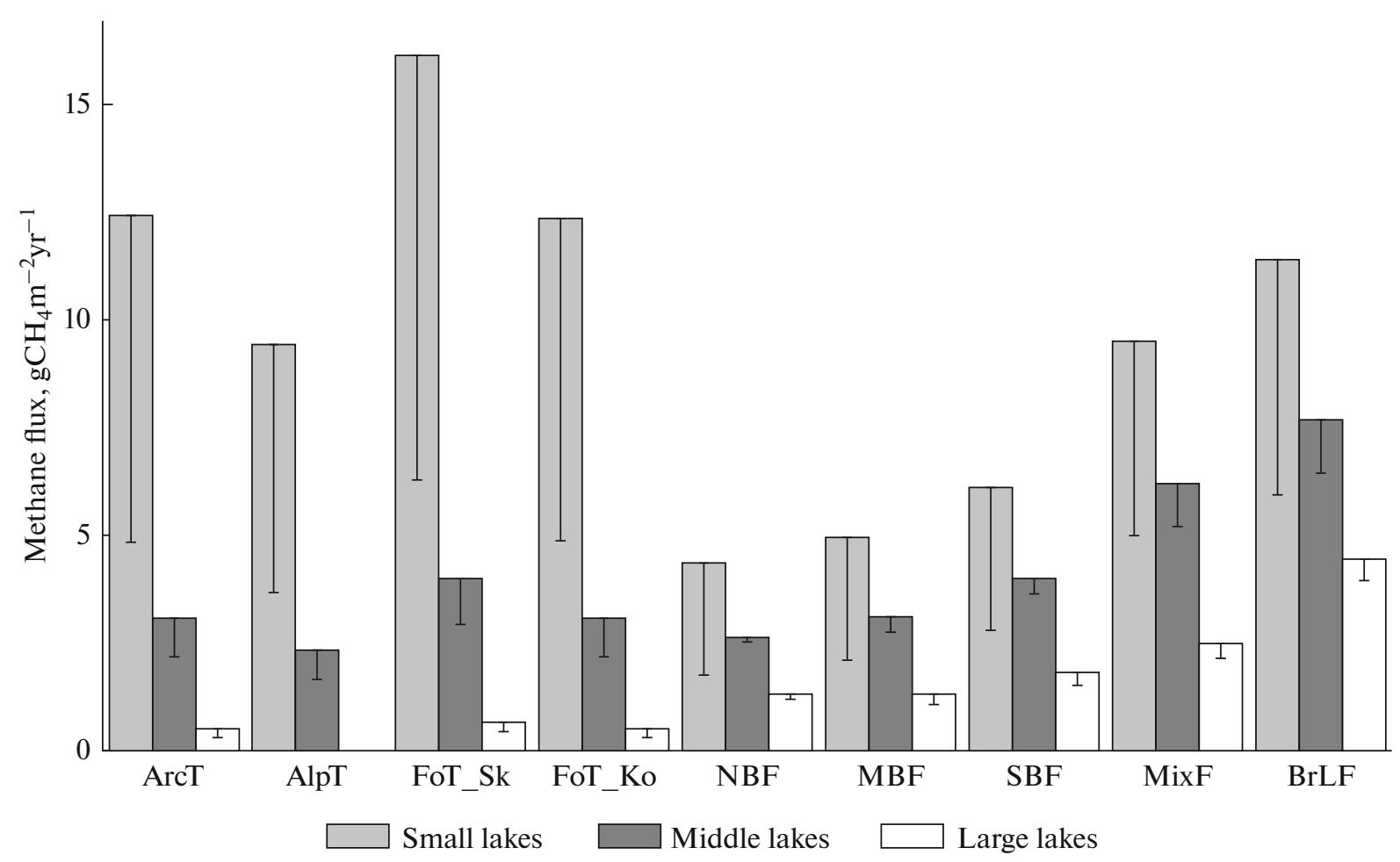

Fig. 3. Estimates of annual methane fluxes into the atmosphere (average values and standard deviations) from the lake size classes for natural zones of Fennoscandia. Names of natural zones are given in Table 1.

lakes in this zone is $7.0 \mathrm{mgCH}_{4} \mathrm{~m}^{-2} \mathrm{~d}^{-1}$ on average and varies over a fairly wide range from 1.0 to $25.6 \mathrm{mgCH}_{4} \mathrm{~m}^{-2} \mathrm{~d}^{-1}[6-8,42,47]$. It follows from [6, $7,36,47]$ that diffusive methane fluxes from middle lakes of the size class of $0.1-1 \mathrm{~km}^{2}$ for mixed forests zone in the region is estimated at $4.4 \mathrm{mgCH}_{4} \mathrm{~m}^{-2} \mathrm{~d}^{-1}$ with a change in the range of $0.7-8.2 \mathrm{mgCH}_{4} \mathrm{~m}^{-2} \mathrm{~d}^{-1}$. According to the same authors, methane fluxes into the atmosphere by molecular diffusion from middle lakes of the size class of $1-10 \mathrm{~km}^{2}$ vary from 0.5 to $6.6 \mathrm{mgCH}_{4} \mathrm{~m}^{-2} \mathrm{~d}^{-1}$ with average value of $2.9 \mathrm{mgCH}_{4} \mathrm{~m}^{-2} \mathrm{~d}^{-1}$. The diffusive methane emission from large lakes for natural zone under study was estimated by us as $1.9 \mathrm{mgCH}_{4} \mathrm{~m}^{-2} \mathrm{~d}^{-1}$ using values of methane fluxes into the atmosphere from Tämnaren lake (area $38 \mathrm{~km}^{2}$ ) [48]. Based on [7, 8, 42] methane fluxes by ebullition into the atmosphere from lakes of the Fennoscandian mixed forests zone are 56-91\% of total methane emission from these lakes over the warm period and the average values are 71 and $80 \%$ for the deep- and shallow-water parts of lakes respectively. It follows from $[10,41]$ that methane emissions through vascular plants from shallow-water parts of mixed forests lakes in the region vary from 63.7 to $277.6 \mathrm{mgCH}_{4} \mathrm{~m}^{-2} \mathrm{~d}^{-1}$.

The obtained estimates for diffusive methane fluxes into the atmosphere from lakes of the Fennoscandian mixed forests zone are close to the average values of similar methane fluxes from Wisconsin lakes $\left(9.5 \pm 4.1 \mathrm{mgCH}_{4} \mathrm{~m}^{-2} \mathrm{~d}^{-1}\right.$ for small lakes and $4.0 \pm$ $2.0 \mathrm{mgCH}_{4} \mathrm{~m}^{-2} \mathrm{~d}^{-1}$ for middle lakes [6]) and much less diffusive methane flux from lakes in Quebec (35.2 $\left.\mathrm{mgCH}_{4} \mathrm{~m}^{-2} \mathrm{~d}^{-1}[49]\right)$. Significant variation in the bubble methane emission from lakes of mixed forests of Fennoscandia is typical for forest lakes of other regions, for instance, Wisconsin lakes (11-80\% [6]).

The contribution of Fennoscandian lakes to the methane budget of the atmosphere. Using data on the methane emissions from lakes in the subarctic region of Sweden, annual methane emissions from lakes of the various size classes for tundra and forest-tundra zones of Fennoscandia are calculated (Fig. 3). It follows from the obtained results that lakes with a surface area less than $0.1 \mathrm{~km}^{2}$ are intensive sources of methane in tundra and forest-tundra zones of Fennoscandia. Annual methane emissions from lakes of this size class lie within the range from 9.5 to $16.2 \mathrm{gCH}_{4} \mathrm{~m}^{-2}$. The contribution of tundra and forest-tundra lakes of Fennoscandia to the methane budget of the atmosphere is estimated as $73 \mathrm{KtCH}_{4}$ per year, in which the portion of methane emissions from lakes in forest-tundra zone of the Scandinavian Peninsula is $80 \%$ (Fig. 4a).

Based on methane emissions from the deep- and shallow-water parts of lakes for boreal zone of Fennoscandia, the annual methane emissions from lakes of northern, middle and southern taiga for the region 
(a)
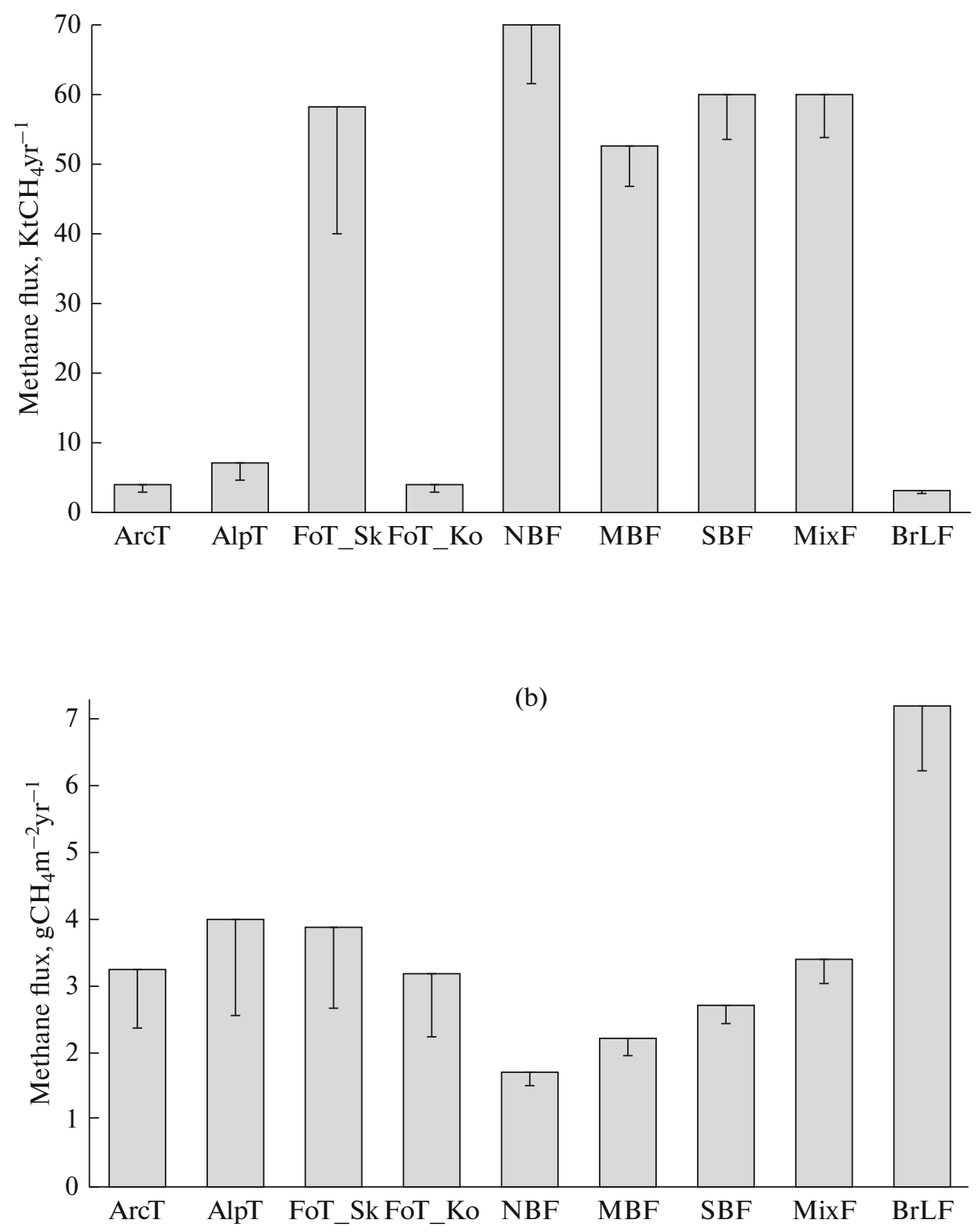

Fig. 4. Estimates of annual methane fluxes into the atmosphere from the lake network (a) and per unit area of lakes (b) for natural zones of Fennoscandia (average values and standard deviations). Names of natural zones are given in Table 1.

under study are estimated (Fig. 3). It is worth noting that when calculating annual methane emissions from large lakes in the northern taiga, we took into account our estimates of the annual methane emissions from Lokka lake and Porttipahta lake (9.2 and $0.2 \mathrm{KtCH}_{4}$ per year respectively) which were obtained based on [25]. According to our calculations, in boreal forests zones of Fennoscandia small lakes are also the most intensive sources of methane per unit area than lakes of larger size classes. Methane emissions from these lakes range from 4.3 to $6.1 \mathrm{gCH}_{4} \mathrm{~m}^{-2} \mathrm{yr}^{-1}$. Note that methane fluxes from small boreal lakes into the atmosphere are lower than the methane emissions from small lakes in tundra and forest-tundra zones of the region under study. The contribution of boreal lakes in Fennoscandia to the methane budget of the atmosphere is about $183 \mathrm{KtCH}_{4}$ per year, with the largest share (about 38\%) in methane emissions from northern taiga lakes (Fig. 4a).

Using estimates of methane emissions from the deep- and shallow-water parts of lakes for mixed forests zone of Fennoscandia, the annual methane fluxes into the atmosphere from lakes of this natural zone and broadleaved forests zone are calculated (Fig. 3). Data on methane fluxes into the atmosphere from lakes of these natural zones during the ice thaw and 
(a)

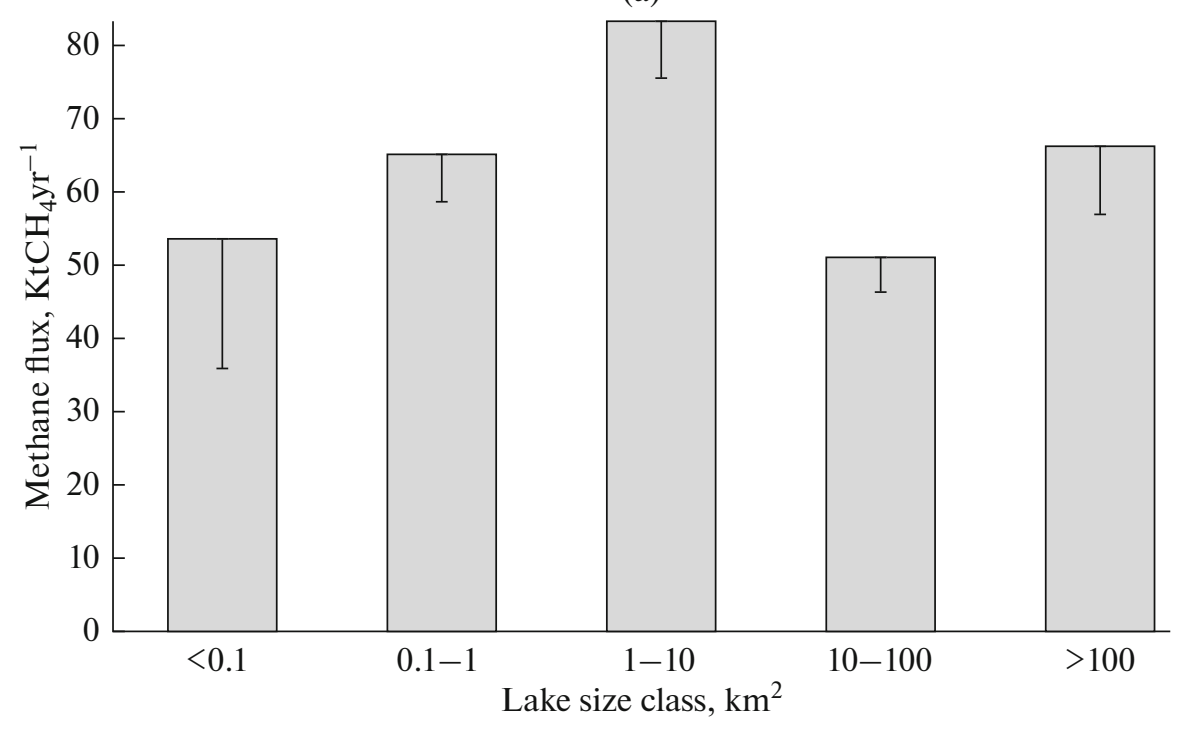

(b)

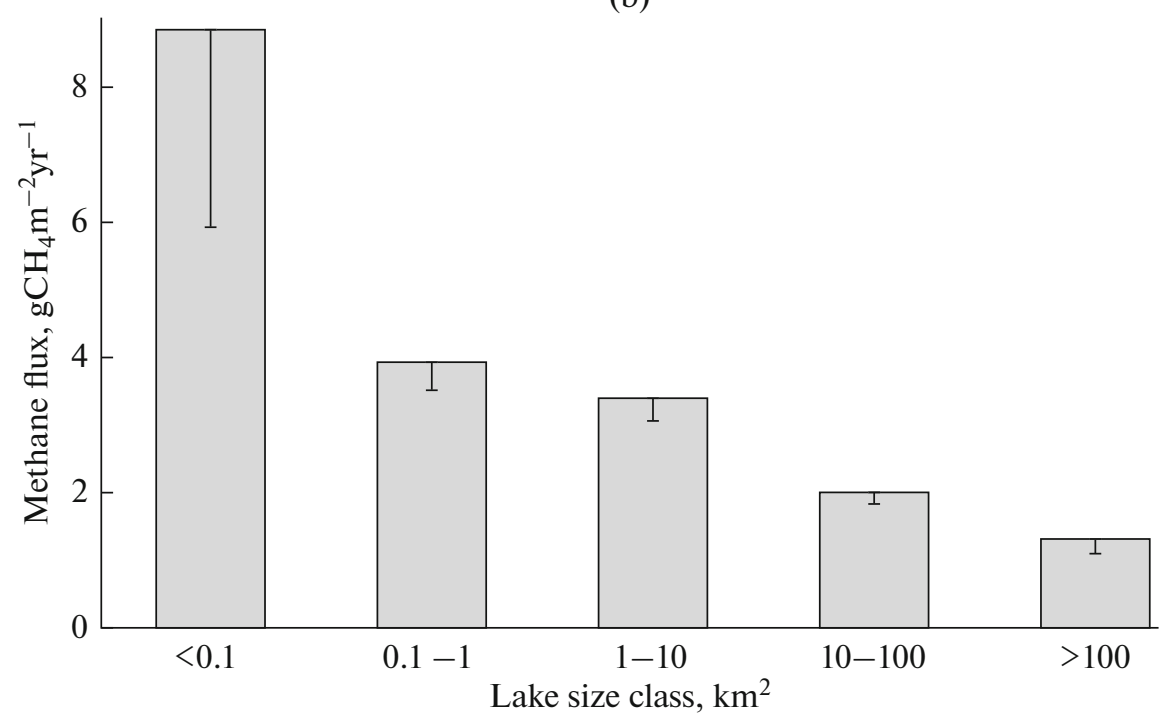

Fig. 5. Estimates of annual methane fluxes into the atmosphere from Fennoscandian lakes for each lake size class (average values and standard deviations): (a) for the lake network, (b) for unit area of lakes.

spring mixing of lake water are absent in publications. No studies have also been carried out to estimate the methane fluxes to the atmosphere by means of vascular plants from shallow-water parts of these lakes in the ice cover period. The value of the short-term spring methane flux into the atmosphere and the value of methane emission from shallow-water parts in the ice cover period from boreal lakes of the region are used as values of the similar methane fluxes from lakes of mixed and broadleaved forests zones. Our calculations show that these lakes emit from 2.5 to $11.4 \mathrm{gm}^{-2} \mathrm{yr}^{-1}$ of methane into the atmosphere. The annual contribution of mixed and broadleaved forest lakes of Fennos- candia to the methane budget of the atmosphere is about $63 \mathrm{KtCH}_{4}$ (Fig. 4a).

Based on the obtained estimates, the small water bodies in Fennoscandia are the most intensive sources of methane per unit area among lakes. Methane emissions from these lakes vary from 4.3 to $16.2 \mathrm{gCH}_{4} \mathrm{~m}^{-2} \mathrm{yr}^{-1}$ (Fig. 3). A number of studies [6, 8, $14,50]$ also point to significant methane fluxes into the atmosphere per unit area from small water bodies.

According to our calculations, the contribution of Fennoscandian lakes to the methane budget of the atmosphere is estimated as $320 \pm 23 \mathrm{KtCH}_{4}$ per year. 
The greatest parts at $19-22 \%\left(60-70 \mathrm{KtCH}_{4} \mathrm{yr}^{-1}\right)$ of the total methane emission from lakes of the region is made by northern and southern taiga lakes and mixed forests lakes (Fig. 4a). Middle taiga lakes and foresttundra lakes of the Scandinavian Peninsula emit about 17-18\% (53-58 $\left.\mathrm{KtCH}_{4} \mathrm{yr}^{-1}\right)$ of the total methane emission from lakes of the region. Lakes of remaining natural zones in Fennoscandia have the insignificant contribution to the total methane emission from the lakes $\left(1-2 \%, 3-7 \mathrm{KtCH}_{4} \mathrm{yr}^{-1}\right)$. It is noted that the highest methane emission per unit area (about $7.2 \mathrm{gCH}_{4} \mathrm{~m}^{-2} \mathrm{yr}^{-1}$ ) is observed for broadleaved forests lakes while the lowest values of one are typical for northern and middle taiga lakes $\left(1.7-2.2 \mathrm{gCH}_{4} \mathrm{~m}^{-2} \mathrm{yr}^{-1}\right)$ (Fig. 4b).

The calculated values of methane fluxes into the atmosphere from Fennoscandian lakes of the various size classes are shown in Fig. 5. The annual methane emissions from lakes with areas less than $0.1,0.1-1.0$, $1-10 \mathrm{~km}^{2}$ are $53 \pm 17,65 \pm 7,83 \pm 8 \mathrm{KtCH}_{4}$ per year respectively (Fig. 5a). Lakes larger than $100 \mathrm{~km}^{2}$ emit about $66 \pm 9 \mathrm{KtCH}_{4}$ per year. Small lakes have higher methane fluxes per unit area into the atmosphere than other lakes of the region, the lower methane fluxes per unit area are typical for large lakes (Fig. 5b).

According to $[3,19]$ the annual methane flux into the atmosphere per unit area of lakes located to the north of $50^{\circ} \mathrm{N}$ is estimated as $8.7 \mathrm{gCH}_{4} \mathrm{~m}^{-2} \mathrm{yr}^{-1}$. From the obtained estimate for the annual methane flux from the lake network of Fennoscandia, it follows that the methane flux rate from lakes of this region is estimated as $2.6 \pm 0.2 \mathrm{gCH}_{4} \mathrm{~m}^{-2} \mathrm{yr}^{-1}$, which is about $30 \%$ of the annual methane flux per unit area of northern lakes.

\section{CONCLUSIONS}

Analysis of databases on water bodies of Fennoscandia showed that lakes of this region occupy about $124 \times 10^{3} \mathrm{~km}^{2}$. Small, medium and large lakes cover 5, 33 , and $62 \%$ of the total Fennoscandian lake area respectively. It should be noted that lakes larger than $100 \mathrm{~km}^{2}$ occupy about $41 \%$ of the total lake area in the region. Globally, the Fennoscandian lake area is $2.2 \%$ of the world lake network area and $6.1 \%$ of the total area for lakes located above $50^{\circ} \mathrm{N}$.

Based on published estimates of the methane emissions from lakes in different natural zones of Finland and Sweden and on our experimental measurements of methane fluxes from lakes in the northern taiga of Karelia, the annual methane emission from the Fennoscandian lake network is obtained. According to the calculations, the contribution of Fennoscandian lakes to the methane budget of the atmosphere is estimated as $320 \pm 23 \mathrm{KtCH}_{4}$ per year. Methane flux into the atmosphere from small lakes in the region equals $17 \%$ of the total methane emission from the lakes under study, from middle and large lakes amounts to 46 and
$37 \%$ respectively. The methane flux per unit area from Fennoscandian lakes is estimated as $2.6 \pm$ $0.2 \mathrm{gCH}_{4} \mathrm{~m}^{-2} \mathrm{yr}^{-1}$, which is about $13 \%$ of the average annual methane emission per unit area of the global lake network. The Fennoscandian methane fluxes are $8.9 \pm 2.9,3.6 \pm 0.3,1.5 \pm 0.1 \mathrm{gCH}_{4} \mathrm{~m}^{-2} \mathrm{yr}^{-1}$ from small, middle and large lakes respectively. Thus among Fennoscandian lakes small lakes are the most intensive sources of atmospheric methane per unit area.

Analysis of measurements of methane fluxes into the atmosphere from Fennoscandian lakes has shown that the bubble methane flux is an essential part in the total methane flux from these lakes over the warm period. Ebullition is estimated as $40-71 \%$ and $21-$ $80 \%$ of the methane emission for the deep- and shallow-water parts of lakes respectively. During the ice cover period methane emission from shallow-water parts of Fennoscandian lakes by means of vascular plants reaches $11-16 \%$ of the annual methane emission from these parts of lakes. According to data on methane effluxes into the atmosphere during ice thaw on Fennoscandian lakes, it is shown that $16-37 \%$ of the annual total methane emission from these water bodies is carried out by methane produced during the ice cover period.

Observed climatic changes in the middle and high latitudes of the northern hemisphere have led the ice cover period on lakes to decrease, to changes in the intensities of biogeochemical processes in the lake water column and bottom sediments [51, 52]. Taking into account the tendency to increase of the methane emissions from northern lakes while reducing the ice cover period on them [19], it is likely that the intensity of the methane effluxes into the atmosphere from the lake network of the region under study will be intensified with the expected climate changes.

\section{ACKNOWLEDGMENTS}

We thank V.S. Kazantsev for his help in processing information about the lake areas and the personnel at Paanajarvi National Park for their assistance in our field research. This work was supported by the Russian Foundation of Basic Research (project no. 14-05-91764) and by the state assignment.

\section{REFERENCES}

1. C. Verpoorter, T. Kutser, D. A. Seekell, and L. J. Tranvik, "A global inventory of lakes based on high-resolution satellite imagery," Geophys. Res. Lett. 41 (1), 6396-6402 (2014).

2. L. J. Tranvik, J. A. Downing, J. B. Cotner, et al., "Lakes and reservoirs as regulators of carbon cycling and climate," Limnol. Oceanogr. 54, 2298-2314 (2009).

3. D. Bastviken, L. J. Tranvik, J. A. Downing, et al., "Freshwater methane emissions offset the continental carbon sink," Science 331, 50 (2011). 
4. M. Saunois, P. Bousquet, B. Poulter, et al., "The global methane budget 2000-2012," Earth Syst. Sci. Data 8, 697-751 (2016).

5. V. F. Gal'chenko, Methanotrophic Bacteria (GEOS, Moscow, 2001) [in Russian].

6. D. Bastviken, J. Cole, M. Pace, and L. Tranvik, "Methane emissions from lakes: dependence of lake characteristics, two regional assessments and a global estimate," Global Biogeochem. Cycles 18, GB4009 (2004).

7. P. Rinta, D. Bastviken, J. Schilder, et al., "Higher late summer methane emission from central than northern European lakes,” J. Limnol. 76 (1), 52-67 (2017).

8. S. Natchimuthu, B. Panneer Selvam, and D. Bastviken, "Influence of weather variables on methane and carbon dioxide flux from a shallow pond," Biogeochemistry 119, 403-413 (2014).

9. J. T. Huttunen, J. Alm, A. Liikanen, et al., "Fluxes of methane, carbon dioxide and nitrous oxide in boreal lakes and potential anthropogenic effects on the aquatic greenhouse gas emissions," Chemosphere 52 (3), 609621 (2003).

10. I. Bergström, S. Mäkelä, P. Kankaala, and P. Kortelainen, "Methane efflux from littoral vegetation stands of southern boreal lakes: An upscaled, regional estimate," Atmos. Environ. 41, 339-351 (2007).

11. P. Kankaala, A. Ojala, and T. Käki, "Temporal and spatial variation in methane emissions from a flooded transgression shore of a boreal lake," Biogeochemistry 68, 297-311 (2004).

12. S. Juutinen, J. Alm, T. Larmola, et al., "Major implication of the littoral zone for methane release from boreal lakes,” Global Biogeochem. Cycles 17 (4), 1117 (2003).

13. P. Kankaala, J. Huotari, E. Peltomaa, et al., "Methanotrophic activity in relation to methane efflux and total heterotrophic bacterial production in a stratified, humic, boreal lake," Limnol. Oceanogr. 51 (2), 11951204 (2006).

14. C. M. Michmerhuizen, R. G. Striegl, and M. E. McDonald, "Potential methane emission from north-temperate lakes following ice melt," Limnol. Oceanogr. 41, 985991 (1996).

15. J. Karlsson, R. Giesler, J. Persson, and E. Lundin, "High emission of carbon dioxide and methane during ice thaw in high latitude lakes," Geophys. Res. Lett. 40 (6), 1123-1127 (2013).

16. J. T. Huttunen, J. Alm, E. Saarijärvi, et al., "Contribution of winter to the annual $\mathrm{CH}_{4}$ emission from a eutrophied boreal lake," Chemosphere 50, 247-250 (2003).

17. H. Miettinen, J. Pumpanen, J. J. Heiskanen, et al., "Towards a more comprehensive understanding of lacustrine greenhouse gas dynamics-two-year measurements of concentrations and fluxes of $\mathrm{CO}_{2}, \mathrm{CH}_{4}$ and $\mathrm{N}_{2} \mathrm{O}$ in a typical boreal lake surrounded by managed forests," Boreal Environ. Res. 20 (1), 75-89 (2015).

18. E. J. Lundin, J. Klaminder, D. Bastviken, et al., "Large difference in carbon emission-burial balances between boreal and Arctic lakes," Sci. Rep. 5, 14248 (2015).

19. M. Wik, R. K. Varner, AnthonyK. Walter, et al., "Climate-sensitive northern lakes and ponds are critical components of methane release," Nature Geosci. 9, 99-105 (2016).

20. A. Sepulveda-Jauregui, K. M. Walter Anthony, K. Martinez-Cruz, et al., "Methane and carbon dioxide emissions from 40 lakes along a north-south latitudinal transect in Alaska," Biogeosciences 12, 31973223 (2015).

21. U. Bohn and G. D. Katenina, Map of the Natural Vegetation of Europe (Scale 1:2500000), Federal Agency for Nature Conservation, Bonn, 2000.

22. A. Henriksen, B. L. Skjelkvale, J. Mannio, et al., "Northern European lake survey - 1995. Finland, Norway, Sweden, Denmark, Russian Kola, Russian Karelia, Scotland and Wales," Ambio 27 (2), 80-91 (1998).

23. Lakes of Karelia. A Handbook, Ed. by N. N. Filatov and V. I. Kukharev (Karel'skii nauchnyi tsentr RAN, Petrozavodsk, 2013) [in Russian].

24. The Finnish Eurowaternet with Information about Finnish Water Resources and Monitoring Strategies, Ed. by J. Niemi, P. Heinonen, S. Mitikka, (Finnish Environ. Inst., Helsinki, 2001).

25. J. T. Huttunen, T. S. Väisänen, S. K. Hellsten, et al., "Fluxes of $\mathrm{CH}_{4}, \mathrm{CO}_{2}$, and $\mathrm{N}_{2} \mathrm{O}$ in hydroelectric reservoirs Lokka and Porttipahta in the northern boreal zone in Finland," Global Biogeochem. Cycles 16 (1), 1003 (2002).

26. L. L. Golubyatnikov and V. S. Kazantsev, "Contribution of tundra lakes in Western Siberia to the atmospheric methane budget," Izv., Atmos. Ocean. Phys. 49 (4), 395-403 (2013).

27. J. Karlsson, T. R. Christensen, P. Crill, et al., "Quantifying the relative importance of lake emissions in the carbon budget of a subarctic catchment," J. Geophys. Res. 115, G03006 (2010).

28. T. R. Christensen, T. Johansson, M. Olsrud, et al., "A catchment-scale carbon and greenhouse gas budget of a subarctic landscape," Phil. Trans. R. Soc. A 365, 1643-1656 (2007).

29. M. Wik, P. M. Crill, R. K. Varner, and D. Bastviken, "Multiyear measurements of ebullitive methane flux from three subarctic lakes,” J. Geophys. Res. 118, 1307-1321 (2013).

30. E. J. Lundin, R. Giesler, A. Persson, et al., "Integrating carbon emissions from lakes and streams in a subarctic catchment,” J. Geophys. Res. 118, 1200-1207 (2013).

31. M. Jammet, S. Dengel, E. Kettner, et al., "Year-round $\mathrm{CH}_{4}$ and $\mathrm{CO}_{2}$ flux dynamics in two contrasting freshwater ecosystems of the subarctic," Biogeosciences 14, 5189-5216 (2017).

32. M. van Hardenbroek, O. Heiri, F. J. W. Parmentier, et al., "Evidence for past variations in methane availability in a Siberian thermokarst lake based on $\delta^{13} \mathrm{C}$ of chitinous invertebrate remains," Quat. Sci. Rev. 66, 74-84 (2013).

33. M. E. Repo, J. T. Huttunen, A. V. Naumov, et al., "Release of $\mathrm{CO}_{2}$ and $\mathrm{CH}_{4}$ from small wetlands lakes in Western Siberia," Tellus B 59, 788-796 (2007).

34. F. Bouchard, I. Laurion, V. Preskienis, et al., "Modern to millennium-old greenhouse gases emitted from ponds and lakes of the Eastern Canadian Arctic (Bylot 
Island, Nunavut)," Biogeosciences 12, 7279-7298 (2015).

35. P. Kankaala, J. Huotari, T. Tulonen, and A. Ojala, "Lake-size dependent physical forcing drives carbon dioxide and methane effluxes from lakes in a boreal landscape," Limnol. Oceanogr. 58 (6), 1915-1930 (2013).

36. M. van Hardenbroek, A. F. Lotter, D. Bastviken, et al., "Relationship between $\delta^{13} \mathrm{C}$ of chironomid remains and methane flux in Swedish lakes," Freshwater Biol. 57, 166-177 (2012).

37. L. L. Golubyatnikov, "Study of methane emissions from northern lakes in Russia," in Ecology, Economics, Informatics, System Analysis and Modeling of Economic and Ecological Systems. Collection of Papers (Yuzhnyi federal'nyi universitet, Rostov on Don, 2015), Vol. 1, pp. 95-97.

38. H. E. Chmiel, J. Kokic, B. A. Denfeld, et al., "The role of sediments in the carbon budget of a small boreal lake," Limnol. Oceanogr. 61, 1814-1825 (2016).

39. J. Lopéz Bellido, E. Peltomaa, and A. Ojala, "An urban boreal lake basin as a source of $\mathrm{CO}_{2}$ and $\mathrm{CH}_{4}$," Environ. Pollut. 159, 1649-1659 (2011).

40. J. T. Huttunen, T. S. Väisänen, M. Heikkinen, et al., "Exchange of $\mathrm{CO}_{2}, \mathrm{CH}_{4}$ and $\mathrm{N}_{2} \mathrm{O}$ between the atmosphere and two northern boreal ponds with catchments dominated by peatlands or forests," Plant Soil 242, 137-146 (2002).

41. P. Milberg, L. Törnqvist, L. M. Westerberg, and D. Bastviken, "Temporal variations in methane emissions from emergent aquatic macrophytes in two boreonemoral lakes," AoB Plants 9, plx029 (2017).

42. S. Natchimuthu, I. Sundgren, M. Galfalk, et al., "Spatio-temporal variability of lake $\mathrm{CH}_{4}$ fluxes and its influence on annual whole lake emission estimates," Limnol. Oceanogr. 61, S13-S26 (2016).

43. J. López Bellido, T. Tulonen, P. Kankaala, and A. Ojala, " $\mathrm{CO}_{2}$ and $\mathrm{CH}_{4}$ fluxes during spring and autumn mixing periods in a boreal lake (Pääjärvi, Southern Finland)," J. Geophys. Res. 114, G04007 (2009).

44. T. Larmola, J. Alm, S. Juutinen, et al., "Contribution of vegetated littoral zone to winter fluxes of carbon dioxide and methane from boreal lakes," J. Geophys. Res. 109, D19102 (2004).

45. C. E. Weyhenmeyer, "Methane emissions from beaver ponds: Rates, patterns, and transport mechanisms," Global Biogeochem. Cycles 13 (4), 1079-1090 (1999).

46. A. R. Phelps, K. M. Peterson, and M. O. Jeffries, "Methane efflux from high-latitude lakes during spring ice melt,” J. Geophys. Res. 103, 29029-29036 (1998).

47. J. Schilder, D. Bastviken, M. van Hardenbroek, et al., "Spatial heterogeneity and lake morphology affect diffusive greenhouse gas emission estimates of lakes," Geophys. Res. Lett. 40, 5752-5756 (2013).

48. E. Podgrajsek, E. Sahlée, D. Bastviken, et al., "Comparison of floating chamber and eddy covariance measurements of lake greenhouse gas fluxes," Biogeosciences 11, 4225-4233 (2014).

49. T. DelSontro, L. Boutet, A. St-Pierre, et al., "Methane ebullition and diffusion from northern ponds and lakes regulated by the interaction between temperature and system productivity," Limnol. Oceanogr. 61 (S1), S62-S77 (2016).

50. M. A. Holgerson and P. A. Raymond, "Large contribution to inland water $\mathrm{CO}_{2}$ and $\mathrm{CH}_{4}$ emissions from very small ponds," Nature Geosci. 9, 222-228 (2016).

51. N. N. Filatov, A. P. Georgiev, T. V. Efremova, et al., "Response of lakes in Eastern Fennoscandia and Eastern Antarctica to climate changes," Dokl. Earth Sci. 444 (2), 752-755 (2012).

52. S. Bertilsson, A. Burgin, C. C. Carey, et al., "The under-ice microbiome of seasonally frozen lakes," Limnol. Oceanogr. 58, 1998-2012 (2013). 